\title{
DEVELOPING THE TEACHING FACTORY LEARNING MEDIA IN A PUBLIC VOCATIONAL HIGH SCHOOL
}

\author{
Sintha Wahjusaputri ${ }^{1 *}$, Elin Marlina ${ }^{1}$, Siti Latifah $^{1}$ \\ ${ }^{1}$ Universitas Muhammadiyah Prof. Dr. HAMKA \\ Jl. Raya Bogor Km. 23 No. 99, Rambutan, Ciracas, Kota Jakarta Timur, DKI Jakarta 13830, \\ Indonesia
}

\begin{abstract}
This study aims to determine the success factors of the learning media of tutorial and skill e-report portfolios video-based in teaching factory learning outcomes in vocational high school. This study was the Research and Development model, through several stages, namely: (1) collecting data; (2) planning; (3) developing draft; (4) conducting initial trials; (5) revising the trial results; (6) conducting trial site research; (7) improving the productivity of the test results, (8) conducting test, (9) completing the final product; and (10) disseminating and implementing the result. This study was conducted at 58 Public Vocational High School, Jakarta. The samples were random sampling, consisting of 59 students majoring in painting and visual communication design in the control class and the experimental class. The instrument was a multiple-choice test sheet (multiple choice) through pre-test and post-test. The results of the study were analyzed using a t-test. The t-test average of the experimental class, Visual Communication Design, was 11.522. The t-test average of the control class was 10.832. Thus, the average learning outcomes of the experimental class were 0.69, which is bigger than in the control class. In the experimental class, Painting Class, the average learning outcome was 67, and the control class was 54.5. Therefore, there was a difference of 12.5 . The hypothesis stated that there were differences in teaching factory learning resulted from the pre-test and post-test experimental classes majoring in Painting and Visual Communication Design. The instructional media of Tutorials and Skill E-Report Portfolio Video-Based got very good responses from students.
\end{abstract}

Keywords: teaching factory, industrial learning, tutorial video learning media, video-based portfolio e-report skill

How to cite: Wahjusaputri, S., Marlina, E., \& Latifah, S. (2020). Developing the teaching factory learning media in a public vocational high school. Jurnal Pendidikan Vokasi, 10(1), 69-79. doi:https://doi.org/10.21831/jpv.v10i1.30222

*Corresponding Author: Sintha Wahjusaputri@sinthaw@uhamka.ac.id

-Department of Management, Faculty of Economics and Business, Universitas Muhammadiyah Prof. Dr. HAMKA

J1. Raya Bogor Km. 23 No. 99, Rambutan, Ciracas, Kota Jakarta Timur, DKI Jakarta 13830, Indonesia 


\section{INTRODUCTION}

The learning process in a vocational high school considers the administration of education so that vocational graduates' objectives are reached properly. The vocational high school learning model is different from high school. Vocational high schools prioritize preparing students to enter the workforce and developing professional attitudes. The research conducted by Wahjusaputri et al. (2019) resulted that the composition of the industrial workforce in Indonesia according to education was dominated by SMK graduates reaching approximately 65\% from 2016 to 2020. Along with the increasing number of vocational graduates' work participation rates in 2018-2019, vocational high school graduates' open unemployment rate is decreasing every year. The composition of the industrial workforce according to education is still dominated by vocational high school graduates reaching approximately $65.4 \%$ from 2016 to 2020, according to the results of research conducted by Wahjusaputri et al. (2019), however, they added that the revitalization of vocational high school in teaching factories as production-based learning improves the competence and competitiveness of vocational students who are ready to work in the business and industrial world or Dunia Usaha-Dunia Industri (DU -DI). Teaching Factory Model is a concept of learning in production/ service-based vocational high schools that refers to standards and procedures applicable in the industry $(D U-D I)$ and is carried out in an atmosphere as is the industry's case. To be competent, the concept of teaching factory learning applies an action-oriented learning approach in a productiontechnology learning environment (Reisinger et al., 2019). Therefore, teaching factory oriented learning combines existing learning, namely Competency-Based Training and Production Based Training. This means that a process of expertise or skill is designed and implemented based on actual procedures and standard operating procedures to produce products in line with market/ consumer demands.

The development of learning media is often arranged in the world of education. Innovation is, indeed, something that is needed to improve the quality of existing education. The problems in the field that researchers found were: (1) there were difficulties in studying the material of painting and visual communication design or Desain Komunikasi Visual (DKV); (2) the unclear lesson instructions; (3) the forms of learning that are still considered difficult to understand; (4) the absence of media that support the student's learning; (5) the need for an effective, efficient and pleasant learning atmosphere. One of the developments of learning media provided to vocational students is using the tutorial and portfolio learning media based on skill e-report video-based to achieve the teaching factory learning outcomes. These learning media use video as a medium to support the learning process. Video media has several advantages, such as displaying visual and audio, attracting attention, and saving time (Sadiman et al., 2007). The concept of teaching factory (learning production) unites learning in the classroom with the work environment to foster real and relevant work and learning experiences according to the needs of the Business and Industrial World. Industrial teaching has two-way knowledge, where the first topic of industrial learning material is the basis of a synergy learning model between vocational and industrial subject programs. The industrial class aims at transferring what happens in industrial/ manufacturing environment activities to student courses in the classroom (Rentzos et al., 2014). Teaching factory learning aims to transfer the learning practices in the production/manufacturing environment to the classroom subjects. This way allows the students to understand what products will be needed by the Business and Industrial World (Mavrikios et al., 2018). The learning in the work environment fosters relevant learning experiences and improves the teacher teaching competencies with industry standards (Chryssolouris et al., 2016). According to Prinz et al. (2016), the use of new communication technology uses physical Cyber-Systems in the manufacturing industry. Manufacture industry has a great influence on students and organizations (schools) with technical innovations in production. Abele et al. (2015) said that in industrial learning, a vocational school must be equipped with learning modules that are industry standard and must have a learning/teaching component and a production component, both services and products. The Business and Industrial World provide a series of learning materials and industry-standard work practices to students in producing an industrial product design standard. Mourtzis et al. (2018) argue that, based on industrial learning, to improve vocational schools' productivity and efficiency, we must apply renewable technology based on digitalization. Baena et 
al. (2017) add that in industrial learning, material learning and technology infrastructure must be integrated. First, the material for the purchase must be in accordance with the needs of the industry. Students are given an industry standardized learning concept by an industrial instructor in producing a product. Industrial learning aims to increase the competence of students who are ready to use according to the business and industrial world's needs. After the explanation of the theory is completed, the students are trained to practice in the workshop/laboratory, in discussion groups (Stavropoulos et al., 2018). Mavrikios et al. (2019) believe that the video data created during group assignments while following the subject is a good way to gain scientific insights in the process of developing student competencies. A study conducted by Stojkić and Bošnjak (2019) believes that to produce industrial learning, the level of education and technological infrastructure must be integrated.

Tvenge and Ogorodnyk (2018) explain that the teaching factory aims to improve students' competence who are adapting/standardizing industrial procedures. This helps students in using technology, one of the technologies carried out through video learning media tutorials based on skill e-report video. Learning media tutorials and portfolio skill e-report videos are learning media that use video to support the learning process. Video media has several advantages that can display visual and audio, attract attention, and save time (Sadiman et al., 2007). Hence, it is concluded that by seeing and hearing, humans are easier to remember. In his research, Al Mamun (2014) explained that video can make the class more interesting, interactive, and effective. The study of Comiskey and McCartan (2011) mentioned that people remember 10\% through reading, 20\% through hearing, $30 \%$ of seeing, and $50 \%$ of hearing and seeing. Therefore, humans are easier to remember by seeing and hearing. Learning with video tutorial media is a follow-up of learning in vocational high schools. Besides, the video tutorial media is also used as an alternative solution to the limitations of existing infrastructure in schools. Before practicing, students learn the practices through video tutorials. From the results of the video tutorial learning, the students' practice videos are more simple, detailed, and repeatable. Video tutorials are lessons that record student activities not only from psychomotor but also record the attitude of the students. This video tutorial provides students the opportunity to observe and evaluate their practical work, both personally and feedback from friends. Skill E-report based portfolios video is made by students when implementing practices following the competency scheme through recordings made by study partners. From this recording, the teacher or instructor evaluates by referring to the video tutorial related to practice preparation, the use of work safety, equipment/machine operation, work steps, work attitude, and the final result. Skill e-report based video portfolios provide flexibility to teachers and students because they are not limited in space and time. The application of skill e-report video adjusts the condition of students' abilities and provides a lot of information so that the evaluation does not stop at the level of answering by memorizing and by direct practice recorded by his friends. This triggers the right brain to function more efficiently for students. Open-ended responses often arise because they require the teacher and students' skills to respond from various sides of the abundant available information.

\section{RESEARCH METHOD}

The research conducted by using the development or research and development (R\&D) model is one of the research models that aim at producing certain products and test the validity and effectiveness of these products in their application. According to Sugiyono (2009), research and development aim to find, develop, and validate a product. The stages of research that carried out in the research strategy and development of teaching factory implementation using video tutorial models and video-based portfolio of e-report skill are: (1) collecting data research; (2) planning; (3) developing product draft; (4) conducting initial field trials; (5) revising the test results; (8) conducting the tests; (9) improving the final product; and (10) disseminating and implementing the results. The research was conducted at 58 SMK Negeri 58, SMEA 33- SMIK Street No.1, RT.3/ RW.1, Bambu Apus, Cipayung, City of East Jakarta (13890). SMKN 58, Jakarta has a unique vocational major, namely Textile Craft. Students are taught various ways and techniques to study textiles as the main material in the Textile Craft department. Starting from weaving, making batik to 
learning macrame techniques. Uniquely, students are free to create as beautiful as possible to produce the desired product. Teaching factory implementation activities at SMK Negeri 58 Jakarta have used learning media on tutorial and skill e-report portfolio video-based as an evaluation to measure their students' competency.

The trial in class X, majoring in Painting and class XI majoring in Visual Communication Design (DKV) at 58 public vocational high school Jakarta, was carried out by dividing each department's class into two groups, namely one experimental class group and one control group. This trial was conducted in accordance with their respective majors. The art department explained the shape of the subject of painting while the Visual Communication Design (DKV) major explains Visual Communication Design. After everything finished, the students were given a questionnaire response to see students' responses to the learning media of Video Tutorials and Skill E-Report Portfolio Based as an alternative assessment of students' attitudes and skills. The data collection test techniques for need assessment were obtained through participatory observation or observation and interviews with the teaching teacher as well as some class X students in the painting department and class XI in the visual communication design (DKV) department. After the data collection test is completed, then the media validation and students' responses were used by the media validation questionnaire and the students' questionnaire responses, then the learning outcomes used a practical test. Media validation data and students' responses used an assessment grid consisting of several indicators. The grid for media validation is presented in Table 1, while the grid for the students' responses is shown in Table 2.

Table 1. Validation Grids of Learning Media Tutorial Video and Skill E-Report Portfolio Based

\begin{tabular}{cll}
\hline Variable & \multicolumn{1}{c}{ Sub Variable } & \multicolumn{1}{c}{ Indicators } \\
\hline Tutorial Video & Material and question & 1. The accuracy of content and questions \\
Learning & & 2. The accuracy of questions and exercises \\
Material & & 3. The clarity of the steps in the video material and questions \\
& & 4. The ease to understand the instructional video \\
& Instructional Video & 1. The correct vocabulary \\
& 2. Providing study assistance \\
& 3. The quality of sound \\
& $\begin{array}{l}\text { 1. Readability } \\
\end{array}$ & 2. Easy to use \\
& 3. Good quality of sound \\
& 4. The matching color with the background \\
& 1. The understadable of the language use \\
& 2. The appropriate grammar used \\
& 3. The communicative language used \\
\hline
\end{tabular}

Table 2. The Grids of Students' Reponses

\begin{tabular}{clll}
\hline Variable & \multicolumn{1}{c}{ Sub Variable } & \multicolumn{1}{c}{ Indicators } \\
\hline Students' & Material & 1. The understandable of content \\
Responses on & & 2. The use of understandable language \\
Video Tutorial & Media Illustrations & 1. The clarity of video images display \\
Learning Media & & 2. The clarity of texts/letters \\
& & $\begin{array}{l}\text { 3. The compatiblity color with the display background } \\
\text { 4. The ease of the meadia use }\end{array}$ \\
& & 5. The attractive media display \\
& Benefit & 1. The media fostering the students' interest \\
& & 2. The media increasing the students' knowledge \\
\hline
\end{tabular}

The learning outcomes were calculated using the t-test by testing the conditions first. The number of painting class $\mathrm{X}$ was 32 students in 58 public vocational high schools located in Jakarta, amounting to two classes. Meanwhile, in the visual communication design class XI was 27, two classes were taken as respondents. 


\section{RESULTS AND DISCUSSION}

\section{Results}

In this study, the validation and reliability test questions were used before testing the hypothesis. The validation and reliability tests of the pretest and posttest questions are used to find out the validity of the questions that would be used as an instrument of knowledge assessment in the control class and experimental class. The validation test was done at 58 public vocational high schools in Jakarta, with the number of respondents in the painting department of 32 students in class $\mathrm{X}$ and the number of questions tested is 30 items. Whereas, in the department of visual communication design or Desain Komunikasi Visual (DKV), the number of respondents is 27 students in class XI, and the number of questions tested is 25 items. The results of the validation test in the form of valid questions are used as research material in the control class and the experimental class at 58 public vocational high schools in Jakarta. The analysis prerequisite test in this study used a question validation test and a question reliability test using Cronbach's Alpha.

\section{Validation Test}

The validation test is used to find out whether the question instrument is valid or invalid. Basic decision making, if $r_{\text {count }}>r_{\text {table }}$, then the instrument is declared valid. If $r_{\text {count }}<r_{\text {table }}$, the instrument question is declared invalid.

Table 3. The Results of Validation of Multiple Choice Questions in the Department of Visual Communication Design (DKV)

\begin{tabular}{cccc}
\hline Number of Item & $\mathbf{r}_{\mathbf{X Y}}$ & $\mathbf{r}_{\text {table }}$ & Information \\
\hline 1 & 0 & 0.381 & Invalid \\
2 & 0.759 & 0.381 & Valid \\
3 & 0.020 & 0.381 & Invalid \\
4 & 0.630 & 0.381 & Valid \\
5 & 0.941 & 0.381 & Valid \\
6 & 0 & 0.381 & Invalid \\
7 & 0 & 0.381 & Invalid \\
8 & 0.941 & 0.381 & Valid \\
9 & 0.240 & 0.381 & Invalid \\
10 & 0.941 & 0.381 & Valid \\
11 & 0 & 0.381 & Invalid \\
12 & 0.941 & 0.381 & Valid \\
13 & 0 & 0.381 & Invalid \\
14 & 0 & 0.381 & Invalid \\
15 & 0 & 0.381 & Invalid \\
16 & 0.112 & 0.381 & Invalid \\
17 & 0.484 & 0.381 & Valid \\
18 & 0.037 & 0.381 & Invalid \\
19 & 0.941 & 0.381 & Valid \\
20 & 0.941 & 0.381 & Valid \\
21 & 0.941 & 0.381 & Valid \\
22 & 0.941 & 0.381 & Valid \\
23 & 0 & 0.381 & Invalid \\
24 & 0.020 & 0.381 & Invalid \\
25 & 1 & 0.381 & Valid \\
\hline
\end{tabular}

Source: Researchers' data (2020)

The results of the analysis in Table 3 show that the output correlation between $r_{\text {counts }}$ compared with $r_{\text {tables }}$ obtained a significant value of 0.05 with the amount of data $(n)=25$, then $r_{\text {table }}$ obtains 0.381 . Table 3 shows that 12 items are validated to 27 students. There are 12 valid items in which the correlation value is above $r_{\text {table }}>0.381$. Meanwhile, 13 items are declared invalid because the correlation value is below the $r_{\text {table }}<0.381$. In conclusion, from the 25 items obtained, 11 items are experimented with, because the correlation value is above $r_{\text {table }} 0.381$. 


\section{Reliability Test}

The reliability test was used to determine the measuring instrument's consistency, whether the measuring instrument used was reliable and remained consistent if the measurement was repeated. For the reliability test, the researchers used Cronbach's Alpha method. If the Alpha value was greater than $r_{\text {table }}$, then the questionnaire items used were stated to be reliable or consistent. Conversely, if the Alpha value was smaller than the $r_{\text {table }}$, then the questionnaire items used were stated to be unreliable or inconsistent. Table 4 is the result of Cronbach's Alpha calculations with SPSS. Based on the results of Cronbach's Alpha, the questionnaire items used were declared to be relatively reliable because the alpha value is greater than the $r_{\text {table }}$.

Table 4. Reliability Result of Painting Class

\begin{tabular}{cc}
\hline Cronbach's Alpha & N of Items \\
\hline 0.833 & 25 \\
\hline
\end{tabular}

Table 5. Validation Result of Multiple-Choice Questions Painting Department

\begin{tabular}{|c|c|c|c|}
\hline Number of Item & $\mathbf{r}_{\mathrm{xy}}$ & $\mathbf{r}_{\text {table }}$ & Information \\
\hline 1 & 0 & 0.349 & Invalid \\
\hline 2 & 0 & 0.349 & Invalid \\
\hline 3 & 0.426 & 0.349 & Valid \\
\hline 4 & 0.290 & 0.349 & Invalid \\
\hline 5 & 0.465 & 0.349 & Valid \\
\hline 6 & 0 & 0.349 & Invalid \\
\hline 7 & 0.043 & 0.349 & Invalid \\
\hline 8 & 0.050 & 0.349 & Invalid \\
\hline 9 & 0.326 & 0.349 & Invalid \\
\hline 10 & 0.300 & 0.349 & Invalid \\
\hline 11 & 0 & 0.349 & Invalid \\
\hline 12 & 0.095 & 0.349 & Invalid \\
\hline 13 & 0.015 & 0.349 & Invalid \\
\hline 14 & 0.351 & 0.349 & Valid \\
\hline 15 & 0.287 & 0.349 & Invalid \\
\hline 16 & 0.275 & 0.349 & Invalid \\
\hline 17 & 0.225 & 0.349 & Invalid \\
\hline 18 & 0.350 & 0.349 & Valid \\
\hline 19 & 0.574 & 0.349 & Valid \\
\hline 20 & 0.503 & 0.349 & Valid \\
\hline 21 & 0.260 & 0.349 & Invalid \\
\hline 22 & 0.340 & 0.349 & Invalid \\
\hline 23 & 0.097 & 0.349 & Invalid \\
\hline 24 & 0.359 & 0.349 & Valid \\
\hline 25 & 0.451 & 0.349 & Invalid \\
\hline 26 & 0.418 & 0.349 & Valid \\
\hline 27 & 0.102 & 0.349 & Invalid \\
\hline 28 & 0.474 & 0.349 & Valid \\
\hline 29 & 0.603 & 0.349 & Valid \\
\hline 30 & 0 & 0.349 & Invalid \\
\hline 31 & 1 & 0.349 & Valid \\
\hline
\end{tabular}

Source: Researchers' data (2020)

The results of the analysis in Table 5 shows that the output correlation between $r_{\text {counts }}$ compared with $r_{\text {tables }}$ obtains a significant value of 0.05 with the amount of data $(n)=31$, then $r_{\text {table }}$ obtains 0.349 . Table 5 shows that 11 items are validated by 32 students. There are 11 valid items in which the correlation value is above $r_{\text {table }}>0.349$. Meanwhile, 20 items are declared invalid because the correlation value is below $r_{\text {table }}<0.349$. Thus, from the 31 items obtained, 11 items are experimented with, because the correlation value is above $\mathrm{r}_{\text {table }} 0.349$. Table 6 presents the result of Alpha Cronbach's calculations Department of Visual Communication Design (DKV). Based on the results 
of Cronbach's Alpha, the questionnaire items used are declared to be relatively reliable because the alpha value is bigger than $r_{\text {table }}$.

Table 6. Reliability Result of Visual Communication Design Class

\begin{tabular}{cc}
\hline Cronbach's Alpha & N of Items \\
\hline 0.354 & 30 \\
\hline
\end{tabular}

\section{Normality Test}

A normality test was used to determine whether the population was normally distributed. The basis of significance or probability value $<0.05$, then the data distribution was not normal, whereas if the significance value or probability value $>0.05$, then the data was normally distributed.

Table 7. Normality Test Results in the Control Class and Experiment Class at the Department of Painting and Visual Communication Design

\begin{tabular}{ccc}
\hline Hypothesis Analysis Test & Asymp. Sig. (2-tailed) & Decision \\
\hline Class Pretest (Painting Test) & 0.269 & Normal \\
Class Posttest (DKV Class) & 0.473 & Normal \\
\hline
\end{tabular}

Source: Researchers’ Data (2020)

Based on Table 7, the pretest and posttest normality of the control class and the experimental class resulted in a significance level of more than 0.05 . It shows that the results of the data's significance in the control class in the painting class is 0.150 , with the results of the significance of the data in the experimental class of 0.269 is normally distributed. The DKV class shows that the results of the pretest and posttest normality of the control class and the experimental class with a significance level are bigger than 0.05 of 0.08 with the results of the significance of the data in the experimental class of 0.473 is normally distributed.

\section{Data Analysis and Hypothesis Testing}

Based on the results of research in the control class and the experimental class, there are differences in the results of the answers to the pretest and posttest questions. The questions consist of 25 multiple choice questions in the visual communication design (DKV) department and 30 multiple choice questions in the painting class.

Table 8. The Results of Pre-test and Post-test in Painting Experiment Class

\begin{tabular}{|c|c|c|c|c|c|}
\hline Respondent & $\begin{array}{c}\text { Pre-Test } \\
\text { Value }\end{array}$ & $\begin{array}{l}\text { Post-Test } \\
\text { Value }\end{array}$ & Respondent & $\begin{array}{c}\text { Pre-Test } \\
\text { Value }\end{array}$ & $\begin{array}{c}\text { Post-Test } \\
\text { Value }\end{array}$ \\
\hline Respondent 1 & 57 & 73 & Respondent 17 & 57 & 73 \\
\hline Respondent 2 & 40 & 57 & Respondent 18 & 55 & 60 \\
\hline Respondent 3 & 50 & 57 & Respondent 19 & 55 & 57 \\
\hline Respondent 4 & 57 & 63 & Respondent 20 & 53 & 77 \\
\hline Respondent 5 & 53 & 73 & Respondent 21 & 56 & 67 \\
\hline Respondent 6 & 50 & 63 & Respondent 22 & 57 & 63 \\
\hline Respondent 7 & 50 & 57 & Respondent 23 & 53 & 57 \\
\hline Respondent 8 & 50 & 57 & Respondent 24 & 60 & 70 \\
\hline Respondent 9 & 57 & 73 & Respondent 25 & 53 & 60 \\
\hline Respondent 10 & 77 & 77 & Respondent 26 & 50 & 73 \\
\hline Respondent 11 & 57 & 73 & Respondent 27 & 53 & 67 \\
\hline Respondent 12 & 53 & 67 & Respondent 28 & 70 & 57 \\
\hline Respondent 13 & 70 & 60 & Respondent 29 & 75 & 90 \\
\hline Respondent 14 & 47 & 80 & Respondent 30 & 85 & 90 \\
\hline Respondent 15 & 47 & 67 & Respondent 31 & 60 & 63 \\
\hline Respondent 16 & 53 & 63 & Respondent 32 & 65 & 60 \\
\hline
\end{tabular}

Table 8 is an assessment of the learning outcomes of Class $\mathrm{X}$ students. Class $\mathrm{X}$ is an experimental class with a total of 32 students whose lowest value is 45 , and the highest value is 85 . The 
posttest results show that the lowest value is 55 , and the highest value is 95 . Based on the research results, in class $\mathrm{X}$ as an experiment class, it is known that after learning using learning media of tutorial and skill e-report portfolios video in delivering painting teaching factory material, students' value has increased.

Table 9. The Results of Pre-test and Post-test in Experimental Classes of Visual Communication Design $(D K V)$

\begin{tabular}{cccccccc}
\hline Respondent & $\begin{array}{c}\text { Pre-Test } \\
\text { Value }\end{array}$ & $\begin{array}{c}\text { Post-Test } \\
\text { Value }\end{array}$ & & Respondent & & $\begin{array}{c}\text { Pre-Test } \\
\text { Value }\end{array}$ & $\begin{array}{c}\text { Post-Test } \\
\text { Value }\end{array}$ \\
\cline { 1 - 3 } Respondent 1 & 57 & 73 & & Respondent 15 & 64 & 88 \\
Respondent 2 & 40 & 57 & & Respondent 16 & 60 & 88 \\
Respondent 3 & 50 & 57 & & Respondent 17 & 60 & 92 \\
Respondent 4 & 57 & 63 & & Respondent 18 & 68 & 92 \\
Respondent 5 & 53 & 73 & & Respondent 19 & 68 & 48 \\
Respondent 6 & 50 & 63 & & Respondent 20 & 16 & 88 \\
Respondent 7 & 50 & 57 & & Respondent 21 & 68 & 92 \\
Respondent 8 & 50 & 57 & & Respondent 22 & 64 & 92 \\
Respondent 9 & 57 & 73 & & Respondent 23 & 48 & 88 \\
Respondent 10 & 77 & 77 & & Respondent 24 & 56 & 88 \\
Respondent 11 & 57 & 73 & & Respondent 25 & 60 & 88 \\
Respondent 12 & 53 & 67 & & Respondent 26 & 60 & 96 \\
Respondent 13 & 70 & 60 & & Respondent 27 & 60 & 88 \\
Respondent 14 & 47 & 80 & & & & \\
\hline
\end{tabular}

Source: Researchers' Data (2020)

Table 9 is an assessment of the learning outcomes of class XII students. The experimental class resulted in class XII pretest, with a total of 27 students has the lowest value of 16 and the highest value of 72, while the posttest resulted in the lowest value of 48 and the highest value of 96. Based on the results in class XII as an experimental class, it is known that after learning using learning media of tutorial and skill e-report portfolio video in submitting teaching factory material, the Visual Communication Design (DKV) has increased.

\section{Hypothesis Test}

From the hypothesis test in Table 10, it is known that the experimental class value is 8.523 with a significance of $0.000, \mathrm{t}_{\text {table }}$ of $\mathrm{df}=31$ is obtained at a significance level of $5 \%$ is 1.684 . Thus, the value of $t_{\text {count }}>t_{\text {table }}(8.523>1.684)$ and the significance value is less than $0.05(\mathrm{p}=0.000$ $<0.05)$. From Table 10, the control class value is 7.580 with a significance of $0.000, \mathrm{t}_{\text {table }}$ of $\mathrm{df}=31$ is obtained at a significance level of $5 \%$ is 1.684 . Thus, the value of $t_{\text {count }}>t_{\text {table }}(7.580>1.684)$ and the significance value is less than $0.05(\mathrm{p}=0.000<0.05)$. It is concluded that there are significant differences in the scores of students learning outcomes in the experimental class and the control class on the effectiveness of instructional media of tutorials and skill e-report portfolio video or there is a difference between the pretest and posttest results of the experimental class and the pretest and post-test results of the control class majoring in painting.

Table 10.The Result of Paired Samples T-Test for Control Class and Experiment Class for Painting

\begin{tabular}{cccc}
\hline Experimental Class & $\mathbf{t}$ & df & Sig (2 tailed) \\
\hline Pair 1 Pretest-Posttest & 8.523 & 31 & .000 \\
Control Class & $\mathrm{t}$ & $\mathrm{df}$ & Sig $(2$ tailed $)$ \\
Pair 1 Pretest-Posttest & 7.580 & 31 & .000 \\
\hline
\end{tabular}

Table 11.The Results of Paired Samples T-Test for Control Class and Experiment Class for Visual Communication Design (DKV)

\begin{tabular}{cccc}
\hline Experimental Class & $\mathbf{t}$ & df & Sig $(\mathbf{2}$ tailed $)$ \\
\hline Pair 1 Pretest-Posttest & 11.522 & 27 & 0.000 \\
Control Class & $\mathrm{t}$ & $\mathrm{df}$ & Sig $(2$ tailed $)$ \\
Pair 1 Pretest-Posttest & 10.832 & 27 & 0.000 \\
\hline
\end{tabular}


From Table 11, the result of the post-test t-test revealed that the average learning outcomes of the visual communication design experimental class (DKV) is 11.522, and the average learning outcomes of the control class is 10.832 . Thus, it is concluded that the average learning outcomes of the experimental class have a difference of 0.69 , which is big compared to the control class. From this Table 11, it is known that the $t$ value is 11.522 , with a significance of 0.000 . The obtained $t_{\text {table }}$ of $\mathrm{df}=27$ at a significance level of $5 \%$ is 1.703 . Thus, the value of $t_{\text {count }}>t_{\text {table }}(11.522>1.703)$ and the significance value is less than $0.05(\mathrm{p}=0.000<0.05)$.

\section{Discussion}

Based on the result in the painting and visual communication design (DKV) group of the control class, there are several deficiencies in the video tutorial learning media product, namely the technique of painting shapes or pictures of objects. According to Cvetkova et al. (2010), video tutorial learning media has a very interesting function and directs students' attention to concentrate on learning material related to the visual meaning displayed. Further research by Summak et al. (2010) explains that technological advances through video tutorial media have some advantages, such as the easy use of video tutorial media; relevant subject matter; the multimedia can be used repeatedly by each student; the addition of visual image features and the layout of the main menu layout is more colorful to attract the attention of students. These advantages certainly improve students' learning outcomes in the field of painting and visual communication design (DKV) and make it easier for students to learn independently. Jaber et al. (2018) stated that the instructional video tutorial media in the learning process, especially painting and visual communication design attracts interests and stimulates students' learning. Research by Azer (2009) explained that the use of video tutorial media in teaching and learning generates new desires and interests, arouses motivation and stimulates learning activities, and even psychologically affects students. Therefore, the use of video tutorial learning media improves students' learning outcomes classically by $85 \%$.

\section{CONCLUSION}

The process of designing video tutorial learning media for competency standards in the major of painting and visual communication design was carried out through four stages, namely: stage of concept creation; the stage of making video tutorials; testing phase; and product distribution stage. The function of video tutorials for the painting and visual communication design (DKV) based on skill e-report illustrates the reality of students' activities during practice related to the competencies being studied or tested, as follows: creating the students' attitudes and behaviors following the world of work that has responsibility answer so that the task is completed under the target; students can easily repeat the steps they have learned just by opening the video as a reference when in the workforce; students have the provisions to promote themselves in the world of work; and with the video, students can inspect related to work attitude, work steps, use of work safety to improve the completion of the next job sheet. Furthermore, based on the research findings, it is concluded that the learning media in teaching factory attracted student's interests and facilitated students in learning.

\section{ACKNOWLEDGMENT}

The researchers would like to thank the Ministry of Education and Culture Directorate of Vocational High School, the Republic of Indonesia as research partner; Research Institute of The Muhammadiyah University of Prof. DR. HAMKA; Director of the UHAMKA Post-Graduate School; principals, teachers, staffs, and students of 58 Public Vocational High School in Jakarta.

\section{REFERENCES}

Abele, E., Metternich, J., Tisch, M., Chryssolouris, G., Sihn, W., ElMaraghy, H., Hummel, V., \& Ranz, F. (2015). Learning factories for research, education, and training. Procedia CIRP, 32(Clf), 1-6. https://doi.org/10.1016/j.procir.2015.02.187 
Al Mamun, M. A. (2014). Effectiveness of audio-visual aids in language teaching in tertiary level [Doctoral thesis. BRAC University, Dhaka]. http://dspace.bracu.ac.bd/xmlui/handle/10361/ 3288

Azer, S. A. (2009). Interactions between students and tutor in problem-based learning: The significance of deep learning. The Kaohsiung Journal of Medical Sciences, 25(5), 240-249. https://doi.org/10.1016/S1607-551X(09)70068-3

Baena, F., Guarin, A., Mora, J., Sauza, J., \& Retat, S. (2017). Learning factory: The path to industry 4.0. Procedia Manufacturing, 9, 73-80. https://doi.org/10.1016/j.promfg.2017.04. 022

Chryssolouris, G., Mavrikios, D., \& Rentzos, L. (2016). The teaching factory: A manufacturing education paradigm. Procedia CIRP, 57, 44-48. https://doi.org/10.1016/j.procir.2016.11.009

Comiskey, D., \& McCartan, K. (2011). Video: An effective teaching aid? An architectural technologist's perspective. Transactions, 8(1), 25-40. https://doi.org/10.11120/tran.2011. 08010025

Cvetkova, B., Andonovska-Trajkovska, D., \& Atanasoska, T. (2010). Values of some strategies of teaching and learning in fine art education. Procedia-Social and Behavioral Sciences, 2(2), 2841-2845. https://doi.org/10.1016/j.sbspro.2010.03.425

Jaber, M. Y., Glock, C. H., \& Zanoni, S. (2018). A learning curve with improvement in process quality. IFAC-PapersOnLine, 51(11), 681-685. https://doi.org/10.1016/j.ifacol.2018.08.397

Mavrikios, D., Georgoulias, K., \& Chryssolouris, G. (2018). The teaching factory paradigm: Developments and outlook. Procedia Manufacturing, 23(2017), 1-6. https://doi.org/10.1016/ j.promfg.2018.04.029

Mavrikios, D., Georgoulias, K., \& Chryssolouris, G. (2019). The teaching factory network: A new collaborative paradigm for manufacturing education. Procedia Manufacturing, 31, 398-403. https://doi.org/10.1016/j.promfg.2019.03.062

Mourtzis, D., Zogopoulos, V., \& Vlachou, E. (2018). Augmented reality supported product design towards industry 4.0: A teaching factory paradigm. Procedia Manufacturing, 23(2017), 207212. https://doi.org/10.1016/j.promfg.2018.04.018

Prinz, C., Morlock, F., Freith, S., Kreggenfeld, N., Kreimeier, D., \& Kuhlenkötter, B. (2016). Learning factory modules for smart factories in industrie 4.0. Procedia CIRP, 54, 113-118. https://doi.org/10.1016/j.procir.2016.05.105

Reisinger, G., Trautner, T., Hennig, M., Alexandra, G. R., Mazak, T., Hold, P., Gerhard, D., \& Mazak, A. (2019). TU Wien pilot factory industry 4.0. Procedia Manufacturing, 31, 200205. https://doi.org/10.1016/j.promfg.2019.03.032

Rentzos, L., Doukas, M., Mavrikios, D., Mourtzis, D., \& Chryssolouris, G. (2014). Integrating manufacturing education with industrial practice using teaching factory paradigm: A construction equipment application. Procedia CIRP, 17, 189-194. https://doi.org/10.1016/ j.procir.2014.01.126

Sadiman, A. S., Rahardjo, R., Haryono, A., \& Rahardjito, R. (2007). Media pendidikan: Pengertian, pengembangan dan pemanfaatannya. Raja Grafindo Persada.

Stavropoulos, P., Bikas, H., \& Mourtzis, D. (2018). Collaborative machine tool design: The teaching factory paradigm. Procedia Manufacturing, 23(2017), 123-128. https://doi.org/ 10.1016/j.promfg.2018.04.004

Stojkić, Ž., \& Bošnjak, I. (2019). Development of learning factory at FSRE, University of Mostar. Procedia Manufacturing, 31, 180-186. https://doi.org/10.1016/j.promfg.2019.03.029 
Sugiyono, S. (2009). Metode penelitian pendidikan pendekatan kuantitatif, kualitatif, dan $R \& D$. Alfabeta.

Summak, M. S., Samancio, M., \& Ba, M. (2010). Technology integration and assesment in educational settings. Procedia - Social and Behavioral Sciences, 2(2), 1725-1729. https:// doi.org/10.1016/j.sbspro.2010.03.973

Tvenge, N., \& Ogorodnyk, O. (2018). Development of evaluation tools for learning factories in manufacturing education. Procedia Manufacturing, 23, 33-38. https://doi.org/10.1016/j. promfg.2018.03.157

Wahjusaputri, S., Fitriani, S., \& Syarif, S. (2019). Canvas model business as an innovation of teaching factory learning in the dashion department of 27 Public Vocational High School, Jakarta. Dinamika Pendidikan, 14(2), 142-154. https://doi.org/10.15294/dp.v14i2.21167 